\title{
Efektivitas Lesson Design Berbasis Hypothetical Learning Trajectory dalam Pembelajaran Faktor yang Mempengaruhi Laju Reaksi
}

\author{
Wiwik Kartika Sari ${ }^{1}$, Ella Izzatin Nada ${ }^{2}$ \\ ${ }^{1,2}$ Program Studi Pendidikan Kimia, Universitas Islam Negeri Walisongo Semarang \\ e-mail: \\ 11wiwik.kartika@walisongo.ac.id \\ 2ellaizzatinnada@walisongo.ac.id
}

\begin{abstract}
.
Learning planning is an important aspect of achieving quality learning. The learning quality can be known from dialogue and activities that occur in the classroom. Effective dialogue will occur when interaction between teacher and student can critically interrogate the topic of the lesson, express and listen to many points of view, and create the student-centered learning process. Effective dialogue is dialogue whose response is anticipated so that learning objectives achieved. Prediction and anticipation of responses can be arranged in a learning trajectory which is commonly called a bypothetical learning trajectory. The research purpose is to analyze the prediction and anticipate of student reponses in lesson design with the student responses during the learning process. This research is a descriptive qualitative research with a sample of 32 students of XI grade. The topic in this study is a factor affecting the reaction rate. The learning process was videotaped and transcribed, the dialogue during the learning process is analyzed its suitability with the prediction of student responses and anticipation of responses that are in lesson design. The analysis results showed that $16 \%$ of student response predictions did not appear, $21 \%$ of student responses were out of predictions and 63\% of responses were in accordance with responses prediction and the tendency of activities during the learning process showed student-centered learning. Through this research, it can be seen that the tasks developed by the teacher, the questions and feedback given at the students response affect the deepness and spaciousness of students thinking.
\end{abstract}

Keyword: lesson design, bypothetical learning trajectory, response prediction

\begin{abstract}
ABSTRAK.
Perencanaan pembelajaran merupakan aspek penting untuk menciptakan pembelajaran yang berkualitas. Kualitas pembelajaran dapat ditinaju dari dialog dan aktivitas yang terjadi di kelas. Dialog yang efektif akan terjadi ketika interaksi antara guru dan siswa dapat secara kritis menginterogasi topik pelajaran, mengekspresikan dan mendengarkan banyak sudut pandang, serta menciptakan proses pembelajaran yang berpusat pada siswa. Dialog yang efektif adalah dialog yang responnnya terantisipasi sehingga tujuan pembelajaran tercapai. Prediksi dan antisipasi respon dapat disusun dalam suatu lintasan pembelajaran yang biasa disebut hypothetical learning trajectory. Tujuan dari penelitian ini adalah untuk menganalisis prediksi respon siswa dan antisipasi respon dalam lesson design dengan respon siswa saat proses pembelajaran serta untuk mengetahui kecenderungan aktivitas pembelajaran. Metode dalam penelitian ini adalah deskriptif kualitatif dengan sampel sebanyak 32 siswa kelas XI. Materi pada penelitian ini adalah faktor yang mempengaruhi laju reaksi. Proses pembelajaran direkam dan ditranskrip, dialog selama proses pembelajaran dianalisis kesesuaiannya dengan prediksi respon siswa dan antisipasi respon yang ada dalam lesson design. Hasil analisis menunjukan bahwa 16\% prediksi respon siswa tidak muncul, 21\% respon siswa diluar prediksi dan 63\% respon sesuai dengan prediksi respon yang telah disiapkan serta kecenderungan aktivitas selama proses pembelajaran menunjukan pembelajaran berpusat
\end{abstract}


pada siswa. Melalui penelitian ini, dapat diketahui bahwa tugas - tugas yang dikembangkan guru, pertanyaan dan umpan balik yang diberikan atas respon siswa mempengaruhi kedalaman dan keluasan pemikiran siswa.

Kata kunci: lesson design, bypothetical learning trajectory, prediksi respon

\section{PENDAHULUAN}

Pembelajaran yang berkualitas tercermin dari bagaimana persiapan sebelum pembelajaran dilakukan. Perencanaan pembelajaran berfungsi sebagai kerangka acuan dan aturan dalam pengembangan pembelajaran yang mengarah pada peningkatan pembelajaran dan mempengaruhi motivasi dan sikap peserta didik(Anggraeni \& Akbar, 2018). Guru sebagai penggerak dalam suatu kelas dituntut agar mampu mempersiapkan kegiatan pembelajaran yang mengakomodir semua aspek. Guru harus mempertimbangkan kebutuhan dan minat siswa ketika mereka merencanakan pelajaran sehingga proses pembelajaran berlangsung secara menyenangkan, interaktif, menantang, dan memotivasi siswa untuk terlibat aktif dalam proses pembelajaran Skenario pembelajaran yang disusun guru sebelum melakukan proses pembelajaran disebut rencana pelaksanaan pembelajaran (RPP). Komponen yang tertuang di dalam RPP memuat hal-hal yang langsung berkaitan dengan aktifitas pembelajaran dalam upaya pencapaian penguasaan kompetensi dasar (Haqiqi, 2019). Komponen dasar RPP ada 11 yaitu (1) identitas mata pelajaran; (2) standar kompetensi: sesuai dengan kurikulum; (3) kompetensi dasar; (4) indikator pencapaian kompetensi; (5) tujuan pembelajaran; (6) materi ajar; (7) alokasi waktu; (8) metode pembelajaran; (9) kegiatan pembelajaran; (10) penilaian hasil belajar; dan (11) sumber belajar. Banyaknya komponen dalam RPP sehingga memakan waktu dalam penyusunannya. Melihat fakta bahwa beban administrasi guru sangat banyak maka menteri pendidikan mencanangkan kebijakan merdeka belajar.

Salah satu aspek kebijakan merdeka belajar adalah perubahan komponen dalam rencana pelaksanan pembelajaran. Adanya pemangkasan terhadap komponen - komponen yang ada dalam RPP sehingga hanya ada 3 komponen inti. Komponen tersebut yaitu tujuan pembelajaran, langkah - langkah pembelajaran (kegiatan), dan penilaian pembelajaran (asesmen) serta komponenkomponen lainnya hanya sebagai pelengkap. Tujuan pembelajaran ditulis dengan merujuk kepada kurikulum dan kebutuhan belajar murid. Kegiatan belajar dan asesmen dalam RPP ditulis secara efisien. Berdasarkan kebijakan merdeka belajar pemerintah menekankan bahwa tujuan, langkah dan asesmen pembelajaran adalah hal utama dalam proses pembelajaran dan ketiga hal tersebut saling berkaitan dan harus berkesinambungan.

Hasil analisis beberapa RPP yang digunakan dalam proses pembelajaran menunjukan bahwa RPP yang disusun oleh guru sudah sesuai dengan tuntutan kurikulum dan sudah memenuhi semua komponen inti dan komponen pelengkap. RPP yang digunakan di Indonesia tidak seperti RPP yang digunakan oleh beberapa negara lain, dimana dalam RPP termuat prediksi respon dan antisipasi respon siswa. Prediksi respons siswa atas situasi pembelajaran serta antisipasinya merupakan faktor penting dalam proses pembelajaran. Seorang guru pada saat merancang sebuah skenario pembelajaran perlu memikirkan hal tersebut. Respon siswa penting dalam suatu proses pembelajaran karena menentukan bagaimana tugas utama dalam proses pembelajaran disusun sehingga dalam membuat perencanaan pembelajaran perlu menuliskan prediksi respon siswa. Prediksi respon siswa sangat penting sehingga dalam membuat prediksi respon siswa harus mempertimbangkan respon apa yang paling mungkin dari kelas secara keseluruhan dengan mempertimbangkan kemungkinan respon dari siswa yang agak lambat belajar dan dari siswa yang cepat belajar (Fujii, 2016). Prediksi respon siswa juga menentukan bagaimana antisipasi yang harus dilakukan.

Antisipasi respon siswa sangat penting karena dapat menjadi acuan bagaimana seharusnya proses pembelajaran dilakukan agar sesuai dengan kemampuan siswa. Suryadi (2010) menyatakan bahwa kurangnya antisipasi didaktis dalam perencanaan pembelajaran dapat berdampak kurang 
optimalnya proses belajar bagi perkembangan siswa. Hal ini disebabkan sebagian respon siswa yang muncul pada saat proses pembelajaran di luar jangkauan pemikiran guru sehingga guru harus mempersiapkan antisipasi respon. Antisipasi tersebut tidak hanya menyangkut hubungan siswamateri akan tetapi juga hubungan guru-siswa. Antisipasi respon siswa bertujuan untuk mengantisipasi perkembangan konseptual siswa dan berkaitan dengan tugas dan pertanyaan pertanyaan yang memungkinkan siswa mengembangkan pemahamannya(Suryadi, 2010). Antisipasi respon siswa sangat terkait dengan bypothetical learning trajectory (Webb, 2006). Sehingga berbagai kemungkinan respon perlu diantisipasi sedemikian rupa sehingga dalam kenyataan proses pembelajaran dapat tercipta dinamika perubahan sesuai kapasitas, kebutuhan, serta percepatan pencapaian tujuan pembelajaran. Analisis situasi belajar dan pengambilan keputusan selama proses pembelajaran berlangsung dapat mendorong terjadinya situasi belajar yang optimal diperlukan upaya maksimal yang harus dilakukan sebelum pembelajaran(Sulistiawati, Suryadi, \& Fatimah, 2015).

Salah satu cara yang dapat digunakan untuk mengakomodir hal tersebut adalah dengan mengembangkan skenario pembelajaran berupa lesson design. Lesson design merupakan sebuah dokumen yang menggambarkan tema pembelajaran, tujuan pembelajaran, koneksi antara materi saat ini dan materi terkait dari pembelajaran sebelum dan sesudahnya, dasar pemikiran untuk pendekatan yang dipilih, rencana terperinci untuk proses pembelajaran serta antisipasi pemikiran siswa.(Lewis, Perry, Friedkin, \& Roth, 2012). Kegiatan utama dalam mengembangkan lesson design adalah menetapkan tujuan pembelajaran dan mengembangkan lintasan belajar atau Hypothetical Learning Trajectory (HLT) untuk mencapai tujuan tersebut. Hypothetical Learning Trajectory terdiri dari tujuan, tugas-tugas, dan hipotesis tentang proses belajar siswa(Simon \& Tzur, 2004).

Simon, et al (2004) menjelaskan bahwa Hypothetical learning trajectory dimaksudkan untuk mengkarakterisasi aspek penting dari pemikiran pedagogis yaitu menentukan tujuan serta membuat tugas yang terhubung dengan pemikiran dan pembelajaran anak-anak. Hypothetical learning trajectory berupa garis diagonal dari ujung kiri bawah menuju bagian kanan atas, garis tersebut berupa lembah dan bukit yang membagi lesson design menjadi 2 bagian. Bagian yang berada diatas garis menggambarkan aktivitas yang akan dilakukan guru berupa tugas - tugas yang harus siswa selesaikan sedangkan bagian yang berada di bawah garis menggambarkan segala aktivitas siswa yang mungkin terjadi selama proses pembelajaran. Aktivitas tersebut dituliskan dalam bentuk prediksi respon siswa. Garis yang membentuk lembah menunjukan tantangan yang diberikan kepada siswa sedangkan garis yang membentuk bukit menunjukan bahwa siswa telah dapat menyelesaikan tantangan tugas yang diberikan oleh guru. Garis yang membentuk bukit dan lembah terus berulang sampai kepada kegiatan akhir dan menggambarkan bahwa tujuan dari proses pembelajaran yang dirancang telah tercapai. Banyaknya lembah dan bukit menunjukan jumlah dari tantangan atau tugas yang diberikan kepada siswa.

Hypothetical learning trajectory mencakup tingkatan tugas yang disusun untuk mengembangkan pemahaman siswa dari tingkatan yang dimiliki ke tingkatan yang lebih tinggi (Wahyuningrum, Supriyatin, \& Kameswari, 2020). Selama persiapan kegiatan pembelajaran guru harus memprediksi bagaimana siswa akan bereaksi terhadap kegiatan tertentu dan ini mengharuskan guru untuk merenungkan dan mengkaji kembali pendekatan pembelajaran yang dipilih (Coenders \& Verhoef, 2019). Keadaan tersebut menuntut guru untuk dapat menduga alur berpikir yang akan dikembangkan siswa selama proses pembelajaran. Guru harus dapat mengantisipasi pemikiran, ide, dan kesulitan siswa ketika memilih metode pembelajaran dan membuat skenario pembelajaran serta harus memperhatikan dan menafsirkan respon siswa yang muncul dan respon yang tidak terprediksi (Yılmaz, Elif Yetkin Özdemir, Çetinkaya, \& Elif Yetkin Özdemir, 2017). Keadaan ini memberikan penekanan bagi guru untuk membangun learning trajectory yang baik sehingga guru mengetahui dan memfokuskan bagaimana proses pembelajaran berlangsung sehingga tujuan pembelajaran tercapai. Hypothetical learning trajectory juga dapat 
digunakan sebagai evaluasi dan refleksi untuk merancang pembelajaran yang dapat mengantisipasi kesulitan belajar siswa(Clements, Wilson, \& Sarama, 2004).

Penelitian ini diterapkan pada materi laju reaksi yaitu faktor yang mempengaruhi laju reaksi. Laju reaksi merupakan salah satu topik esensial dalam kimia karena berkaitan dengan materi kimia lainnya. Materi laju reaksi memiliki banyak konsep abstrak, hal ini membuat banyak ditemukan hambatan belajar siswa. Faktor yang mempengaruhi laju reaksi merupakan bagian dari kinetika kimia. kinetika kimia dianggap sebagai konsep yang sulit dipahami oleh siswa dan mahasiswa (Cakmakci, 2010). Konsep - konsep dalam kinetika kimia sangat penting karena mempelajari jenis reaksi, hubungan antara perubahan kimia dan energi kimia serta proses perubahannya (Kolomuç \& Tekin, 2011). Topik yang dipelajari antara lain faktor yang mempengaruhi laju reaksi, teori tumbukan, energi aktivasi, katalis, entalpi, dan mekanisme reaksi.

Berdasarkan latarbelakang tersebut penelitian ini dilakukan dengan tujuan untuk mengetahui efektivitas penerapan lesson design berbasis bypothetical learning trajectory dalam pembelajaran kimia pada materi faktor yang mempengaruhi laju reaksi. Efektivitas lesson design ditinjau dari kesesuaian antara prediksi respon siswa dan respon siswa ketika proses pembelajaran berlangsung. Selain itu juga untuk melihat kecenderungan aktivitas siswa dalam proses pembelajaran di kelas. Melalui penelitian ini, kedalaman dan keluasan pemikiran siswa dikaji dari bagaimana kemampuan guru untuk melakukan pembelajaran, memperoleh ide siswa dengan menggunakan pertanyaan dan teknik scaffolding serta bagaimana memberikan umpan balik dari respon siswa.

\section{METODOLOGI}

Penelitian ini merupakan penelitian kualitatif yaitu berupa penelitian disain didaktis (Didactical Design Research). Penelitian ini dilakukan di salah satu sekolah menengah di Bandung, Indonesia. Subjek penelitian adalah 36 siswa Program Sains kelas 11 yang terdiri dari 24 siswa perempuan dan 12 siswa laki - laki. Topik pada penelitian ini yaitu faktor yang mempengaruhi laju reaksi. Metode penelitian yang digunakan adalah deskriptif kualitatif. Instrumen yang digunakan dalam penelitian ini adalah lesson design. Lesson design disusun dan dikembangkan bersama sama dengan tim dosen dan guru. Lesson design yang sudah jadi kemudian dilakukan uji validitas yaitu uji validitas desain dan construt dengan metode judgment expert. Judgment expert ini dilakukan oleh 2 orang dosen dan 1 guru sekolah menengah atas. Proses pembelajaran direkam dan ditranskrip. Hasil transkrip kemudian dianalisis untuk mengetahui kesesuain antara prediksi respon siswa dan antisipasi respon yang ada di lesson design dengan dialog yang terjadi selama proses pembelajaran dan untuk mengetahui kecenderungan aktivitas antara guru dan siswa dalam proses pembelajaran.

\section{TEMUAN DAN PEMBAHASAN}

Efektivitas penerapan lesson design berbasis hypothetical learning trajectory ditinjau dari 2 aspek yaitu kesesuaian prediksi respon dengan respon siswa ketika proses pembelajaran berlangsung dan kecenderungan aktivitas siswa selama proses pembelajaran. Prediksi respon siswa merupakan hal yang penting dalam proses pembelajaran. Adanya prediksi respon siswa membuat guru lebih mudah dalam membuat skenario pembelajaran dan tugas - tugas sehingga tujuan pembelajaran tercapai. Berdasarkan hasil penelitian tentang kesesuaian prediksi respon siswa dan respon siswa ketika proses pembelajaran diperoleh data yang disajikan pada Gambar 1. 


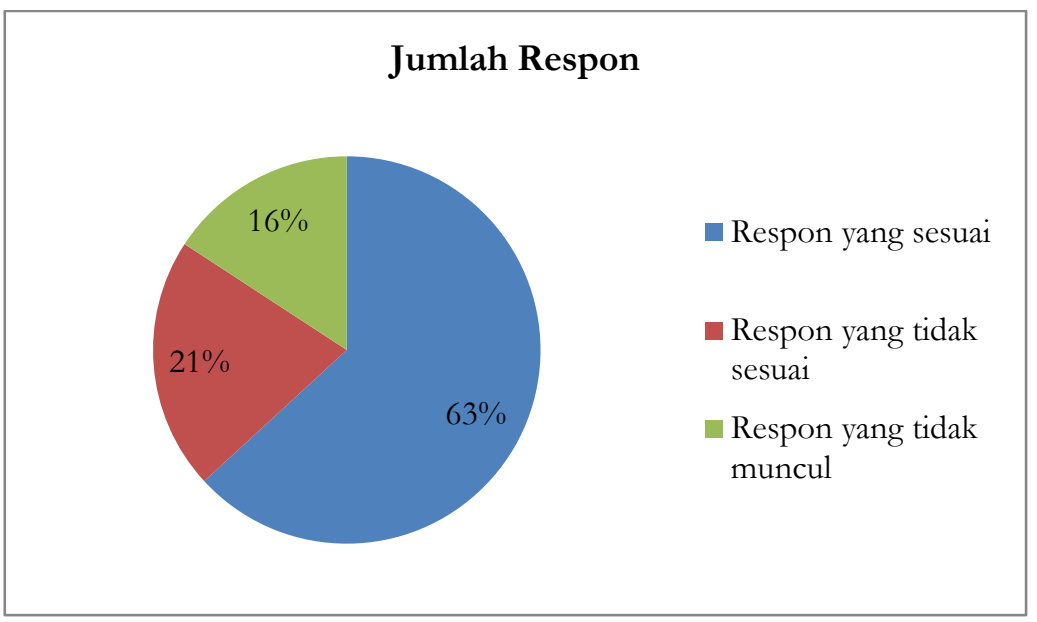

Gambar 1. Data jumlah respon

Berdasarkan data yang ditampilkan pada Gambar 1. dapat disimpulkan bahwa tugas tugas yang ada dalam bypothetical learning trajectory sudah baik. Hal ini karena bentuk antisipasi didaktis sebelum proses pembelajaran dan saat proses pembelajaran membantu siswa dalam mengkontruksi ide - ide sehingga dapat memberikan respon yang sesuai. Hal tersebut ditunjukan dengan hanya 16\% prediksi respon siswa yang tidak muncul dan $21 \%$ respon siswa diluar prediksi respon yang telah disusun dan 63\% respon siswa memiliki tingkat kesesuaian yang sama dengan prediksi respon yang disusun. Hal ini menunjukan bypothetical learning trajectory berhasil dalam mengarahkan proses pembelajaran sehingga berlangsungnya kegiatan pembelajaran di kelas sesuai dengan alur pembelajaran yang disusun. Dalam proses pembelajaran guru perlu memperhatikan kesesuaian tugas yang disusun dalam rencana pelajaran dengan kemungkinan solusi yang diberikan oleh siswa. Oleh karena itu guru harus memperhatikan kemungkinan solusi siswa yang harus diantisipasi. Sehingga selama proses pembelajaran guru harus menentukan strategi yang paling tepat untuk mengatasi situasi didaktis dan pedagogis yang terjadi. Karakteristik tugas yang dikembangkan mempengaruhi proses berpikir siswa dan solusi yang ditemukan oleh siswa(Fujii, 2016). Respon siswa yang lebih rinci disajikan dalam Gambar 2.

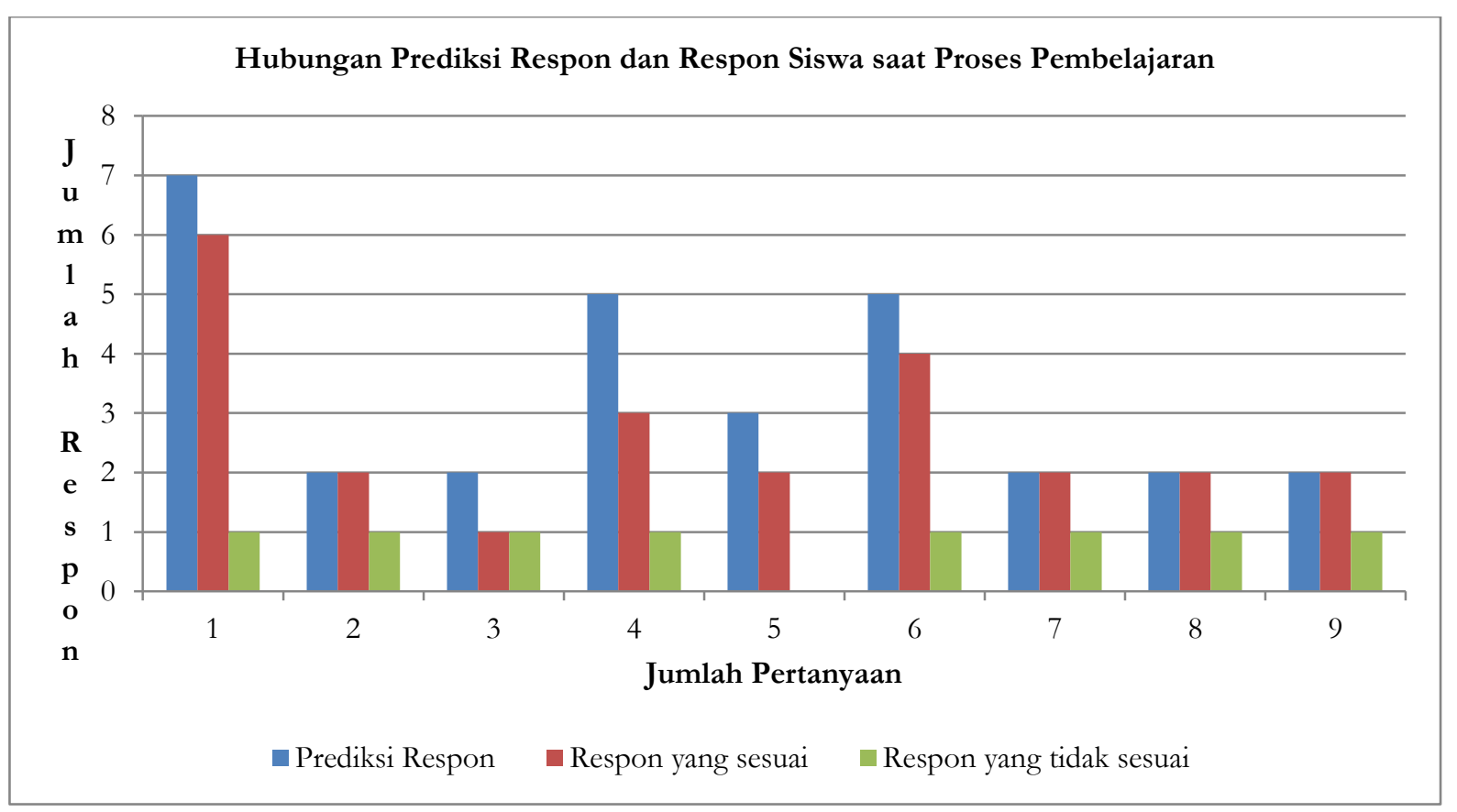

Gambar 2. Grafik hubungan prediksi respon siswa dengan respon siswa saat proses pembelajaran 
Gambar 2. menyajikan hubungan prediksi respon siswa dengan respon siswa saat proses pembelajaran berlangsung. Berdasarkan gambar diatas diketahui bahwa ada 9 pertanyaan yang merupakan bagian dari tugas - tugas dalam lesson design yang dihubungkan dengan bypothetical learning trajectrory. Pertanyaan - pertanyaan tersebut disusun untuk mencapai tujuan pembelajaran. Tujuan pembelajaran yang ingin dicapai adalah siswa dapat memjelaskan faktor - faktor yang mempengaruhi laju reaksi dan penerapannya dalam kehidupan sehari - hari. Berdasarkan informasi yang ada pada grafik dapat diketahui bahwa respon siswa untuk setiap pertanyaan inti saat proses pembelajaran belum semuanya sesuai dengan prediksi respon yang telah disusun. Skenario, prediksi respon, serta antisipasinya yang sudah dipikirkan sebelum kegiatan pembelajaran terjadi pada hakekatnya hanyalah sebuah rencana yang belum tentu sesuai kenyataan(Suryadi, 2010). Sebagaimana dijelaskan sebelumnya, respon tidak selalu sesuai prediksi sehingga berbagai antisipasi yang sudah disiapkan perlu dimodifikasi selama proses kegiatan pembelajaran berlangsung. Hal ini sangat penting untuk dilakukan sebagai konsekuensi logis dari pandangan bahwa pada hakekatnya siswa atau mahasiswa memiliki otoritas untuk mencapai suatu memampuan atas kapasitasnya sendiri(Suryadi, Yulianti, \& Enjun, 2011). Sementara guru sebagai fasilitator, bisa melakukan tindakan pada saat siswa benar-benar membutuhkan yaitu ketika berusaha mencapai kemampuan potensialnya. Oleh karena itu antisipasi yang sudah disiapkan perlu senantiasa disesuaikan dengan situasi didaktis maupun pedagogis yang terjadi.

Salah satu contoh pertanyaan yang ada dalam lesson design pembelajaran faktor yang mempengaruhi laju reaksi adalah pertanyaan mengenai kegiatan percobaan yang akan dilakukan. Percobaan pertama yang akan dilakukan adalah percobaan untuk mengetahui pengaruh luas permukaan terhadap laju reaksi. Guru menyiapkan pertanyaan utama untuk menstimulasi pemikiran siswa tentang bagaimana pengaruh perbedaan bentuk terhadap laju reaksi. Percobaan yang dilakukan adalah mereaksikan larutan $\mathrm{HCl}$ dengan cangkang telur. Percobaan dilakukan dengan cara mereaksikan cangkang telur dalam 2 bentuk yang berbeda yaitu serbuk cangkang telur dan kepingan cangkang telur. Reaksi dilakukan dalam tabung reaksi yang kemudian ditutup dengan dengan balon. Sebelum pencampuran dilakukan, guru menanyakan kemungkinan apa saja yang bakal terjadi. Pertanyaan dan prediksi respon yang disusun disajikan dalam Tabel 1.

Tabel 1. Prediksi respon siswa

\begin{tabular}{|c|c|c|c|c|}
\hline Pertanyaan & Prediksi Respon & Respon yang sesuai & $\begin{array}{c}\text { Respon yang } \\
\text { tidak sesuai }\end{array}$ & Antisipasi respon \\
\hline $\begin{array}{l}\text { Perhatikan } \\
\text { percobaan } \\
\text { yang akan } \\
\text { dilakukan, } \\
\text { percobaan } \\
\text { antara larutan } \\
\text { HCl dengan } \\
\text { prediksikan apa } \\
\text { yang akan } \\
\text { terjadi dengan } \\
\text { kedua } \\
\text { percobaan } \\
\text { tersebut? }\end{array}$ & $\begin{array}{l}\text { 1. Terjadi reaksi } \\
\text { 2. Cangkang telur larut } \\
\text { 3. Reaksi menghasilkan } \\
\text { gelembung } \\
\text { 4. Reaksi menghasilkan } \\
\text { gas } \mathrm{CO}_{2} \\
\text { 5. Laju reaksi antara } \\
\text { gelas kimia } 1 \text { dan } \\
\text { gelas kimia } 2 \text { berbeda } \\
\text { 6. Reaksi yang } \\
\text { menggunakan serbuk } \\
\text { lebih cepat } \\
\text { 7. Balon akan } \\
\text { mengembang }\end{array}$ & $\begin{array}{l}\text { 1. Terjadi reaksi } \\
\text { 2. Balon akan } \\
\text { mengembang } \\
\text { 3. Terdapat } \\
\text { gelembung } \\
\text { 4. Reaksi yang satu } \\
\text { lebih cepat } \\
\text { 5. Cangkang telur } \\
\text { larut } \\
\text { 6. Reaksi } \\
\text { menghasilkan gas }\end{array}$ & $\begin{array}{l}\text { Reaksi yang } \\
\text { menggunakan } \\
\text { kepingan } \\
\text { cangkang telur } \\
\text { lebih cepat }\end{array}$ & $\begin{array}{l}\text { Apa kandungan } \\
\text { utama dari cangkang } \\
\text { telur? }\end{array}$ \\
\hline
\end{tabular}

Berdasarkan Tabel 1. Dapat disimpulkan bahwa respon siswa saat proses pembelajaran berlangsung sesuai dengan prediksi respon yang disusun. Sebanyak 7 respon yang muncul untuk pertanyaan pertama dalam proses pembelajaran, 6 respon sesuai dengan prediksi respon yang disusun. Hasil ini menunjukan bahwa alur pembelajaran dan tugas yang disusun dalam lesson design memudahkan dalam mencapai tujuan pembelajaran. Hal ini menunjukan bahwa bypothetical learning trajectory efektif dalam mencapai tujuan pembelajaran dan mampu membantu siswa dalam 
mengembangkan pemahaman dan mengkonstruksi ide - ide dengan rangsangan bantuan pertanyaan dari guru yang dilakukan secara scaffolding. Guru yang memfasilitasi penyelidikan dengan teknik scaffolding lebih efektif daripada pengajaran konvensional dalam memciptakan perubahan konseptual karena proses pembelajaran menekankan dialog pembelajaran yang merangsang pemikiran dan pengembangan praktik dialog argumentatif (Ravenscroft, 2007). Learning trajectory mencakup tingkatan pemahaman yang disusun untuk mengembangkan pola berpikir siswa. Hypothetical learning trajectory telah terbukti berhasil dalam meningkatkan kemampuan belajar siswa dan keterampilan proses sains siswa terdiri dari tujuan belajar siswa, tugas-tugas yang akan digunakan dalam proses pembelajaran siswa, dan hipotesis tentang proses belajar siswa(Wijaya, 2015). Hypothetical learning trajectory juga efektif dalam meningkatkan kemampuan proses sains siswa dalam pembelajaran materi sifat koligatif larutan dan dalam meningkatkan kemampuan guru untuk mengatasi masalah belajar yang dialami siswa dan dapat mengembangkan kemampuan belajar siswa(Akbar, 2018).

Efektivitas lesson design berbasis bypothetical learning trajectory selain ditinjau dari kesesuain respon siswa dan capaian tujuan pembelajaran juga ditinjau dari kecenderunagn aktivitas siswa selama proses pembelajaran. Proses pembelajaran di kelas sesuai dengan tuntutan pembelajaran abad 21 dan perkembangan kurikulum di Indonesia haruslah pembelajaran yang berpusat pada siswa (student-centered learning) guru hanya sebagai fasilitator. Proses pembelajaran direkam dan hasilnya ditranskrip untuk mengetahui bagaimana kecenderungan aktivitas siswa dan guru dalam proses pembelajaran. Apakah aktivitas pembelajaran sudah berpusat pada siswa atau pembelajaran masih berpusat pada guru. Kecenderungan aktivitas siswa dan guru selama proses pembelajaran disajikan dalam Gambar 3.

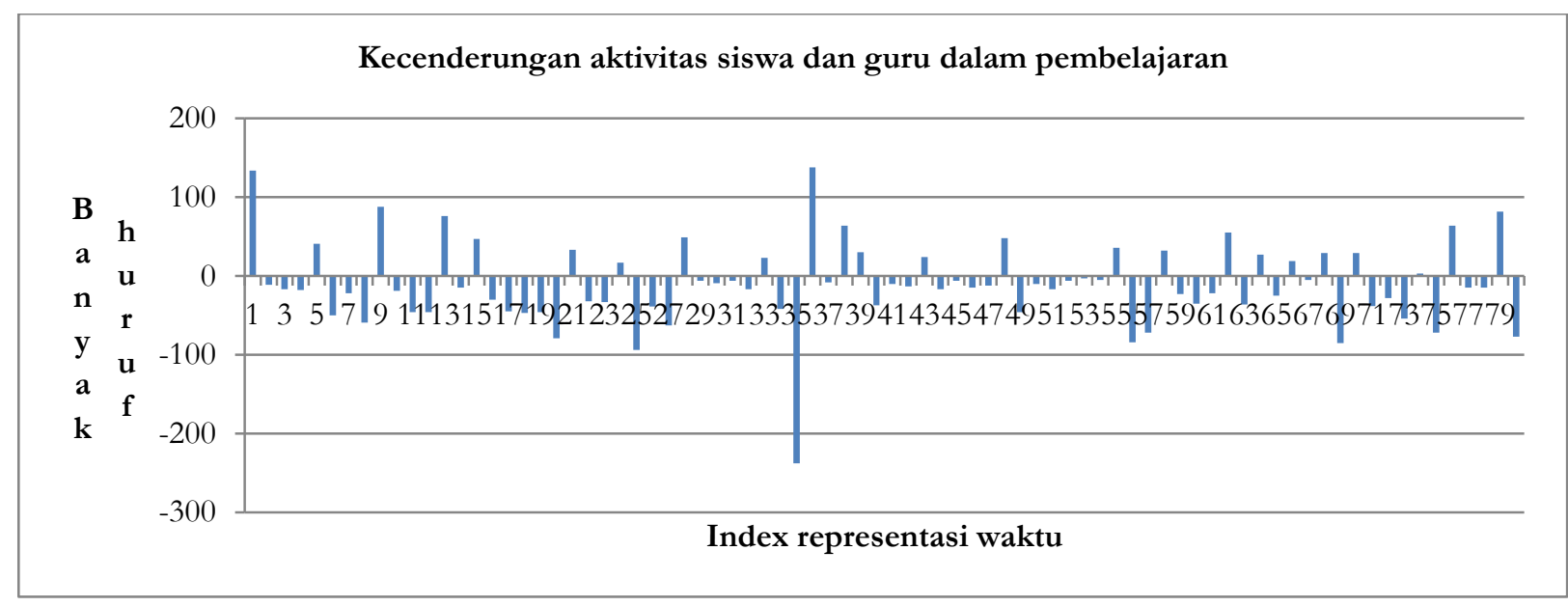

Gambar 3. Grafik kecenderungan aktivitas siswa dan guru dalam pembelajaran

Gambar di atas merupakan grafik yang menggambarkan hubungan banyaknya kata yang diucapkan oleh guru dengan banyaknya kata yang diucapkan oleh siswa. Sumbu y positif merupakan grafik aktivitas guru yang menunjukan banyaknya kata yang diucapkan oleh guru. Sedangkan sumbu y negatif merupakan grafik aktivitas siswa yang menunjukan kata yang diucapkan oleh siswa. Dialog yang terjadi selama proses pembelajaran, tidak semuanya dianalisis dan diolah untuk mengetahui kecenderungan aktivitas dalam proses pembelajaran. Hanya dialog dialog yang menunjukan interaksi didaktis maupun pedagogis antara guru dengan siswa dan siswa dengan siswa.

Berdasarkan grafik pada gambar 3. dapat disimpulkan bahwa aktivitas siswa lebih banyak dari pada aktivitas yang dilakukan oleh guru selama proses pembelajaran. Hal ini menunjukan bahwa kegiatan pembelajaran yang terjadi di dalam kelas sudah bersifat student-centered. Kecenderungan proses pembelajaran yang berpusat pada siswa dipengaruhi oleh tugas - tugas yang disusun oleh guru dan kemampuan guru dalam memberikan antisipasi respon terhadap 
respon yang diberikan oleh siswa. Berbagai instuksi yang merangsang siswa untuk mengkonstruksi ide dan intruksi berbasis penyelidikan yang diberikan oleh guru merupakan hal yang menciptakan proses pembelajaran yang berpusat pada siswa(Keiler, 2018). Siswa cenderung merespon secara positif terhadap perubahan-perubahan yang ada selama proses pembelajaran dan para guru menganggap diri mereka berhasil dalam upaya untuk menciptakan proses pembelajaran yang lebih berpusat pada siswa dengan variasi tugas - tugas yang telah disusun (Brown Wright, 2011). Grafik di atas merupakan hasil analisis proses pembelajaran pada kegiatan sharing task 1 yang ada dalam lesson design. Berdasarkan pemaparan hasil dan pembahasan diketahui bahwa lesson design berbasis byphotetical learning trajectory efektif dalam pembelajaran kimia khususnya pada materi faktor yang mempengaruhi laju reaksi.

Implikasi dari penelitian yang telah dilakukan adalah penggunaan lesson design berbasis bypothetical learning trajectory yang memuat prediksi respon dan antisipasi respon siswa membuat proses pembelajaran lebih terstruktur dan terarah sehingga tujuan pembelajaran tercapai dengan baik. Selain itu, guru tugas - tugas yang disusun oleh guru memfasilitasi siswa berdiskusi dengan siswa lainnya terkait materi pembelajaran sehingga siswa dapat membangun konsep pengetahuannya sendiri. Selain itu, proses pembelajaran yang dilakukan juga dapat membangun karakter siswa seperti komunikatif, toleransi, peduli, dan meningkatkan rasa ingin tahu. Hasil penelitian menunjukan bahwa bypothetical learning trajectory efektif dalam menciptakan proses pembelajaran yang berpusat pada siswa tetapi karena keterbatasan waktu sehingga penelitian ini baru diterapkan pada satu topik saja yaitu faktor yang mempengaruhi laju reaksi. Oleh karena itu diperlukan penelitian lebih lanjut untuk mengetahui efektivitas lesson design berbasis bypothetical learning trajectory pada topik kimia yang lain.

\section{SIMPULAN}

Lesson design berbasis hypothetical learning trajectory efektif dalam proses pembelajaran materi faktor yang mempengaruhi laju reaksi. Analisis kesesuaian prediksi respon menunjukan sebanyak $16 \%$ prediksi respon siswa yang tidak muncul, $21 \%$ respon siswa diluar prediksi respon dan $63 \%$ respon siswa saat proses pembelajaran sesuai dengan prediksi respon yang telah disiapkan. Selain itu Lesson design berbasis bypothetical learning trajectory efektif dalam menciptakan proses pembelajaran yang berpusat pada siswa (student-centered learning). Bagi para guru dalam membuat rencana pelaksanaan pembelajaran penting untuk menuliskan prediksi respon dan antisipasi respon siswa dengan bantuan bypothetical learning trajectory.

\section{REFERENSI}

Akbar, S. A. (2018). Profil Kemampuan Analisis Respon Sekolah Menengah Atas melalui Hypothetical Learning Trajectory (HTL) pada Materi Sifat Koligatif Larutan. Jurnal Serambi Akademica, IV(2), 85-90.

Anggraeni, P., \& Akbar, A. (2018). Kesesuaian Rencana Pelaksanaan Pembelajaran Dan Proses Pembelajaran. Jurnal Pesona Dasar, 6(2), 55-65. https:// doi.org/10.24815/pear.v6i2.12197

Brown Wright, G. (2011). Student-Centered Learning in Higher Education. International Journal of Teaching and Learning in Higher Education, 23(3), 92-97. Retrieved from http://www.isetl.org/ijtlhe/

Cakmakci, G. (2010). Identifying alternative conceptions of chemical kinetics among secondary school and undergraduate students in Turkey. Journal of Chemical Education, 87(4), 449-455. https://doi.org/10.1021/ed8001336

Clements, D. H., Wilson, D. C., \& Sarama, J. (2004). Young Children's Composition of 
Geometric Figures: A Learning Trajectory. Mathematical Thinking and Learning, 6(2), 163-184. https://doi.org/10.1207/s15327833mt10602

Coenders, F., \& Verhoef, N. (2019). Lesson Study: professional development (PD) for beginning and experienced teachers. Professional Development in Education, 45(2), 217-230. https://doi.org/10.1080/19415257.2018.1430050

Fujii, T. (2016). Designing and adapting tasks in lesson planning: a critical process of Lesson Study. ZDM - Mathematics Education, 48(4), 411-423. https://doi.org/10.1007/s11858-0160770-3

Haqiqi, A. K. (2019). Telaah Implementasi Kurikulum 2013: Tinjauan Pada Rencana Pelaksanaan Pembelajaran (RPP) Mata Pelajaran Ilmu Pengetahuan Alam. Journal of Natural Science and Integration, 2(1), 12. https://doi.org/10.24014/jnsi.v2i1.7110

Keiler, L. S. (2018). Teachers' roles and identities in student-centered classrooms. International Journal of STEM Education, 5(34), 1-20. https://doi.org/10.1186/s40594-018-0131-6

Kolomuç, A., \& Tekin, S. (2011). Chemistry Teachers' Misconceptions Concerning Concept of Chemical Reaction Rate. Eurasian Journal of Physics Chemistry Education, 3(2), 84-101. Retrieved from http://www.eurasianjournals.com/index.php/ejpce

Lewis, C. C., Perry, R. R., Friedkin, S., \& Roth, J. R. (2012). Improving Teaching Does Improve Teachers: Evidence from Lesson Study. Journal of Teacher Education, 63(5), 368-375. https://doi.org/10.1177/0022487112446633

Ravenscroft, A. (2007). Promoting thinking and conceptual change with digital dialogue games. Journal of Computer Assisted Learning, 23(6), 453-465. https://doi.org/10.1111/j.13652729.2007.00232.x

Simon, M. A., \& Tzur, R. (2004). Explicating the Role of Mathematical Tasks in Conceptual Learning: An Elaboration of the Hypothetical Learning Trajectory. Mathematical Thinking and Learning, 6(2), 91-104. https://doi.org/10.1207/s15327833mt10602

Sulistiawati, Suryadi, D., \& Fatimah, S. (2015). Desain Didaktis Penalaran Matematis untuk Mengatasi Kesulitan Belajar Siswa SMP pada Luas dan Volume Limas. Jurnal Matematika Kreatif - Inovatif, 6(2), 135-146.

Suryadi, D. (2010). Menciptakan Proses Belajar Aktif: Kajian dari Sudut Pandang Teori Belajar dan Teori Didaktik. $\quad$ Retrieved from http://didisuryadi.staf.upi.edu/files/2011/06/MENCIPTAKAN-PROSES-BELAJAR-AKTIF.pdf

Suryadi, D., Yulianti, K., \& Enjun, J. (2011). Model Antisipasi dan Situasi Didaktis dalam Pembelajaran Matematika Kombinatorik Berbasis Pendekatan Tidak Langsung. Retrieved from http://didisuryadi.staf.upi.edu/files/2011/06/MODEL-ANTISIPASI-DAN-SITUASI-

DIDAKTIS.pdf

Wahyuningrum, A. S., Supriyatin, T., \& Kameswari, D. (2020). Pengembangan Antisipasi Didaktis dan Pedagogis Pembelajaran Matematika dan Ilmu Pengetahuan Alam (IPA). Jurnal PKM: Pengabdian Kepada Masyarakat, 3(1), 12-21.

Webb, M. M. (2006). What Does It Mean To Preservice Mathematics Teachers To Anticipate Student Responses?

Wijaya, A. F. C. (2015). Profil Kemampuan Analisis Respon Siswa melalui Hypothetical Learning Trajectory ( HLT ) sebagai Instrumen Pembelajaran dalam Pengembangan Beragam Kemampuan Siswa. Prosiding Simposium Nasional Inovasi Dan Pembelajaran Sains, (Snips), 185188.

Yılmaz, N., Elif Yetkin Özdemir, I., Çetinkaya, B., \& Elif Yetkin Özdemir, İ. (2017). Anticipating students' thinking through Lesson Study: A case study with three prospective middle school mathematics teachers. Proceedings of CERME 10, 3399-3407. Retrieved from https://hal.archives-ouvertes.fr/hal-01949136 